\title{
„Niebo bez ptaków”. O jednym z toposów literatury lagrowej (i jego obrzeżach)
}

\author{
Jakże to... No, jak... pamiętacie... Późną jesienią przelatują \\ ptaki... Długie, bardzo długie klucze. Wali artyleria, nasza i nie- \\ miecka, a one lecą. Jak do nich krzyknąć? Jak je uprzedzić: „Tu nie \\ wolno! Tutaj strzelają!”. Jak?! Ptaki padają, spadają na ziemię... \\ S. Aleksijewicz, Wojna nie ma $w$ sobie nic z kobiety ${ }^{1}$
}

Zadanie, przed którym stanąłem jako autor prezentowanego tu studium, określić mógłbym jako szczególny rodzaj archeologii. Archeologii, która wspierając się na ruchomym fundamencie relektury wybranych wspomnień lagrowych, postara się odtworzyć - na tyle, na ile to możliwe - jeden z aspektów światoodczucia osób uwięzionych za drutami niemieckich obozów koncentracyjnych (bo to właśnie kacetom w głównej mierze poświęcony będzie mój szkic). Przystępując do tak pojętych poszukiwań, wektor swojej uwagi chciałbym skierować w stronę, która dotąd ze zrozumiałych powodów była słabiej, jeśli w ogóle eksponowana.

Już od pierwszych chwil po wyzwoleniu lagrów (a nawet wcześniej) historycy badający koncentracyjne uniwersum zobligowani byli „zabezpieczyć ślady", innymi słowy, z maksymalnym pietyzmem odtworzyć genezę nazistowskich obozów koncentracyjnych i obozów masowej zagłady, ich wewnętrzną organizację, a nade wszystko warunki bytowe, w jakich przyszło żyć i umierać więźniom i więźniarkom. Nie powinno zatem dziwić, że w ramach tak zaprojektowanej rekonstrukcji szczegółowej analizie poddawano system przemocy, katalog regulaminowych i nieregulaminowych kar oraz szykan, na jakie narażeni byli uwięzieni, kwestię wyżywienia, a raczej głodowych racji obozowych, odzież, pozostającą w dyspozycji członków więźniarskiej populacji, a także warunki mieszkalne, na jakie ich skazano.

* Dr hab.; Uniwersytet Szczeciński, Wydział Filologiczny, Instytut Polonistyki i Kulturoznawstwa, Zakład Literatury i Kultury Polskiej XIX wieku; Al. Piastów 40B, 71-065 Szczecin; krupier10@wp.pl.

${ }^{1}$ S. Aleksijewicz, Wojna nie ma w sobie nic z kobiety, przeł. J. Czech, Wydawnictwo Czarne, Wołowiec 2015, s. 148. 
Nie porzucając z pola widzenia tych krzyżujących się sfer, w całości determinujących lagrowy los, w swoich rozważaniach - jak sygnalizowałem - spróbuję podjąć wątek, który dotąd był nieobecny, względnie lokował się na odległych peryferiach historycznej i historycznoliterackiej refleksji dotyczącej piśmiennictwa obozowego. Rzec mógłbym, że jako badaczowi tej jakże zróżnicowanej konstelacji literackiej przyszło mi zmierzyć się z wyzwaniem paradoksalnego rodzaju; oto bowiem, starając się dodać kolejny element do z wolna wykuwającego się glosariusza topiki piśmiennictwa lagrowego i piśmiennictwa Zagłady ( ${ }^{2}$ ak wiemy skądinąd, choć są to obszary rozłączne, to „linia demarkacyjna między nimi nie jest łatwa do wytyczenia”3), zamierzam skoncentrować się nie na tym, co w tej literaturze jest, ale na tym, co występuje jako brak, luka, z rzadka tylko uwidoczniony rewers. Kontynuując grę paradoksami, raz jeszcze podkreślę, że intrygować mnie będzie intensywna obecność nieobecności, „,czynne zanikanie”"4, bo tak, najkrócej to ujmując, należałoby rozumieć tytułowe ,puste niebo”, „niebo bez ptaków”, niebo, które oniemiało, zamilkło...

\section{Gdzie nie śpiewają ptaki?}

Ta osobliwa figura w literaturze lagrowej powraca z zaskakującą regularnością. Odnajdziemy ją - w dwóch przypadkach pojawia się nawet w przestrzeni tytułu! - m.in. we wspomnieniach Seweryny Szmaglewskiej, Zofii Posmysz, Karoliny Lanckorońskiej, Danuty Brzosko-Mędryk czy Janiny Fabierkiewicz-Szyrkowej. Przytoczę jedynie dwa przykłady:

Zwłoki rozstrzelanych palono w krematorium, przytykającym do wysokiego, chyba pięciometrowego muru otaczającego obóz. Komin krematorium wystawał ponad mur i wiatr przyganiał dym między bloki - rudy, duszący dym, śmierdzący spalonymi kośćmi. Odór ten ciągnie się za mną po dzień dzisiejszy. Odstraszał on chyba ptaki, bo jakaż mogła być inna przyczyna tego, że nigdy nie widziałyśmy tu gromadki swarzących się wróbli czy śmigających jaskółek? Czasem tylko wysoko w górze krążyły jastrzębie, jakby symbol naszych władców. A obóz był przecież położony

\footnotetext{
${ }^{2}$ Nawiązuję tu do badań prowadzonych przez Sławomira Buryłę (zob. rozdział Topika Holokaustu. Wstępne rozpoznanie, w: tenże, Wokót Zagłady. Szkice o literaturze Holokaustu, Universitas, Kraków 2016; Tematy [nie]opisane, Universitas, Kraków 2013; Pociagi śmierci - kilka uwag o konstrukcji hasła stownikowego, „Narracje o Zagładzie” 2016, nr 2) oraz Zespół Badań Pamięci o Zagładzie Instytutu Kultury Polskiej UW (zob. Ślady Holokaustu w imaginarium kultury polskiej, red. J. Kowalska-Leder [i in.], Wydawnictwo Krytyki Politycznej, Warszawa 2017). Topice holokaustowej poświęcony został również monograficzny numer „Narracji o Zagładzie” (2016, nr 2).

${ }^{3}$ S. Buryła, Monografia po latach, „Teksty Drugie” 2009, nr 5, s. 104.

${ }^{4}$ Wypożyczam tu koncept Jeana Baudrillarda. Zob. tenże, Spisek sztuki, przedm. S. Lotringer, przeł. S. Królak, Wydawnictwo Sic!, Warszawa 2006, s. 46.
} 
wśród lasów nad brzegiem jeziora i wydawałoby się, że nie powinno tu braknąć tej skrzydlatej czeredy; tym bardziej że i na odpadkach nie zbywało w naszym pięćdziesięciotysięcznym „mieście"5.

Toteż gdy tę część obozu ogarnie nagła obiadowa cisza, wymykamy się kuchennym wyjściem i rzucamy w kępę chwastów i ostrej trawy, w której, jak zagubione szkolne farbki, jaśnieją żółcią kwitnące mlecze.

Leżymy milcząc, nie unosząc głowy, by nas nie zobaczyli Niemcy, i wdychamy ostry zapach ziela.

Przypominają mi się - gdzieś przecież jeszcze istniejące - łąki pełne miękkiej trawy, kaczeńców i postrzępionych, odurzających, dzikich lila goździków, w których brzęczą pszczoły i trzmiele.

Ale na próżno szukam zapachu ziemi, mimo że tę majdankową przekopujemy wielokrotnie i głęboko, ciągle przerzucając łopatami. Nie pachnie dobrą, życiodajną glebą. Jest sucha, bez thustego połysku, jakby i z niej już wyssano życie, jałowa. I niebo nad nią bez ptaków, które daremnie szukałyby tu pokarmu ${ }^{6}$.

Już na tym etapie rozważań warto podkreślić, że, po pierwsze, to kobiety częściej zwracały uwagę na ten szczególny rys „kamiennego świata”, po drugie, zauważmy, iż wymienione autorki były więźniarkami różnych obozów: Birkenau, Majdanka, Ravensbrück, co jednoznacznie sugeruje, że skonstatowany tu fenomen miał charakter ponadlokalny i był niejako niezależny od tak obiektywnych, wydawałoby się, czynników, jak rzeźba terenu czy szeroko pojęte warunki przyrodnicze danego miejsca, w którym Niemcy zdecydowali się ulokować obóz. Ale zajmujące nas zagadnienie nieco się skomplikuje, gdy zauważymy, że na ślady owej figury - „nieba bez ptaków”, względnie „nieba wypełnionego ptactwem, które uporczywie milczy" - natkniemy się również poza obszarem interesującego nas piśmiennictwa. Na przykład w relacjach z oblężonego Leningradu', we współczesnych opisach lasu skrywającego mogiły ofiar zbrodni katyńskiej ${ }^{8}$, a nawet - przesuńmy wskazówki historycznego zegara - w naocznej relacji z miejsca katastrofy polskiego samolotu rządowego w Smoleńsku.

${ }^{5}$ J. Fabierkiewicz-Szyrkowa, Gdzie nie śpiewały ptaki, Książka i Wiedza, Warszawa 1972, s. $86-87$.

${ }^{6}$ D. Brzosko-Mędryk, Niebo bez ptaków, Wydawnictwo Ministerstwa Obrony Narodowej, Warszawa 1969, s. 193.

${ }^{7}$ B. Pawletko, Blokada Leningradu i jej reprezentacje w świetle innych doświadczeń granicznych, „Śląsk” - Stowarzyszenie Inicjatyw Wydawniczych, Katowice 2016, s. 192-193.

${ }^{8}$ Mowa o reportażu radiowym Jana Kasi, dotyczącym grupy pielgrzymującej na groby polskich oficerów zamordowanych w Charkowie. Zob. Tam, gdzie nie śpiewaja ptaki [online], http:// www.polskieradio.pl/9/325/Artykul/219711,Tam-gdzie-nie-spiewaja-ptaki-Reportaz-Jana-Kasi [dostęp: 15.03.2017]. Emisja: Program 3 Polskiego Radia.

${ }^{9}$ Tam nawet ptaki nie śpiewaja. 5. rocznica katastrofy smoleńskiej [online], http://czestochowskie24.pl/czestochowa/45350/ [dostęp: 15.03.2017]. 
Jeśli będziemy pamiętać o tej koincydencji, może się okazać, że utrwalonym w kulturze przedstawieniom obszarów, „gdzie nie śpiewają ptaki”, rzeczywiście przypisać można status loci communes, ale będą to miejsca na tyle pojemnej wspólnoty, by zdołała pomieścić różnego rodzaju historyczne doświadczenia. Co łączyłoby będące ich wyrazem narracje? Z pewnością silne nacechowanie martyrologiczne, niezacieralny ślad przeobrażającego psychicznego wstrząsu, jakiego doznał obserwujący podmiot, ale wydaje się, że powinniśmy zwrócić uwagę na coś jeszcze. Coś, co skrótowo można by tu określić jako rys hiperboliczny przywołanych świadectw, swoisty retoryczny naddatek, mający artykułować niepokojącą prawdę: wobec zbrodni przekraczających horyzont ludzkiej wyobraźni nikt i nic nie powinno pozostać obojętne. Dotyczyłoby to również przyrody, w tym jej ważnych emisariuszy - ptaków. W tle prezentowanych przeze mnie obozowych relacji tliłoby się zatem podświadome przekonanie, szczególna forma presupozycji, oparta na - pozwólmy sobie na pewien anachronizm - adornowskim schemacie. Swoje traumatyczne przeżycia narratorzy i narratorki lokowaliby w kręgu takich historycznych kataklizmów, po których chciałoby się ,zakazać ptakom śpiewu, kwiatom rozkwitania, a słońcu blasku”10. Problem ten z innej strony oświetli tytuł (para)autobiograficznych zapisków Josepha Horace’a „Jima” Greasleya, angielskiego jeńca wojennego, który podczas II wojny światowej wsławił się wielokrotnymi ucieczkami z oflagów - Do the Birds Still Sing in Hell? (Czy w piekle ptaki nadal śpiewają? $)^{11}$.

Pozostańmy jeszcze przez chwilę na progu charakterystycznego dla literatury lagrowej dantejskiego wyobrażenia, porównującego zacieśniającą się przestrzeń wojennej opresji - zmaterializowaną w postaci gęstej sieci stalagów, oflagów, obozów pracy niewolniczej, obozów koncentracyjnych i obozów zagłady - do kolejnych kręgów ziemskiego piekła ${ }^{12}$. Piekła pojmowanego również jako miejsce, do którego można zstąpić, ale z którego nie ma i nie powinno być powrotu. Ta na poły metafizyczna wizja poniekąd nakładałaby się na nazistowski plan Endlösung, rozumiany jako wydarzenie, które w intencji inżynierów ludo-

${ }^{10}$ J. Makowski, Czy po Auschwitz da się jeszcze pisać wiersze? [online], http://makowski.blog. polityka.pl/2015/01/27/czy-po-auschwitz-da-sie-jeszcze-pisac-wiersze/ [dostęp: 15.03.2017].

${ }^{11}$ H. Greasley, K. Scott, Do the Birds Still Sing in Hell?, John Blake Publishing, London 2013. Polski przekład: H. Greasley, Czy w piekle ptaki nadal śpiewaja? Prawdziwa historia człowieka, który stawił czoła nazistom. Wszystko z miłości do kobiety, przeł. O. Kwiecień, Editio, Gliwice 2015.

${ }^{12}$ Oto jeszcze jeden przykład podobnego nawiązania w prozie dotyczącej lagrów: „Ale skąd miał wiedzieć? Któż to mógł odgadnąć, przeczuć? Ona przecież także pojęcia nie miała, póki się tutaj nie znalazła. Nikt normalny nie mógł sobie tego wyobrazić. Dante, Kafka, Czapek? Te wizje były zbyt ogólnikowe, nie uwzględniały szczegółów ani udręki nieopisanej rozciągłości czasu tortury. Może średniowieczni malarze piekieł zbliżali się do prawdy, malując te kłębowiska ciał stłoczonych na decymetrze kwadratowym płótna niczym kijanki w małych stawkach wiejskich?", Z. Posmysz, Ten sam doktor M, Iskry, Warszawa 1981, s. 185. 
bójstwa miało być w całości pozbawione świadków ${ }^{13}$. To, że ów makiaweliczny projekt ostatecznie się nie powiódł, w głównej mierze zawdzięczamy ocaleńcom oraz tym, którzy choć sami nie zdołali przeżyć, zdążyli pozostawić świadectwa. Jak się wydaje, jest jeszcze jedna - zdecydowanie najmniej liczna - grupa świadków, do której należałoby zaliczyć osoby, które dobrowolnie migrowały w głąb nazistowskiego ,jądra ciemności”. Tym razem myślę nie o słynnym rotmistrzu Pileckim, ale o kolejnym (po Josephie Greasley’u) angielskim jeńcu wojennym, który - podobnie jak legendarny polski oficer - wsławił się jako „człowiek, który wkradł się do Auschwitz"14. Przywołując jego wspomnienie, chciałbym, po raz pierwszy w tym studium, położyć akcent na szczególnie istotną, choć rzadko dostrzeganą, symetrię, na której ślady natrafić możemy na kartach lagrowego i holokaustowego piśmiennictwa. W ramach tej paraleli Zagłada podlegałaby osobliwej multiplikacji, rozszczepiając się niejako na dwa dopełniające się wcielenia: genocyd oraz ekocyd ${ }^{15}$.

Byłem w jenieckim obozie pracy E715 w Monowicach niedaleko Auschwitz przez 18 miesięcy. Uwierz mi, Auschwitz było miejscem niemożliwym do opisania. Nawet przyroda się stamtąd wyniosła. Nie było ptaków, pszczół ani motyli. Drzewa nie miały liści, a trawa była szara. Myślałem, że nawet Bóg się obraził na to miejsce. Było tam samo zło. To było piekło. Każdego dnia widziałem, jak ludzie byli wykorzystywani, poniżani i zabijani ${ }^{16}$.

Jak zatem widzimy, a właściwie słyszymy, wibrujące milczenie ptaków przez ofiary nazistowskiej przemocy interpretowane jest przynajmniej na dwa sposoby. Podczas gdy jeden z nich, wychylony niejako „na zewnątrz”, akcentowałby towarzyszący zagładzie ludzkich istnień proces degradacji środowiska, nieznane dotąd formy biologicznego kolapsu, sprawiające, że na doświadczenie Auschwitz dałoby się spojrzeć nie tylko jako na „dziurę w dziejach”"17, ale również jako na niedającą się zasypać wyrwę w relacjach pomiędzy człowiekiem a naturą, o tyle drugi z nich kierowałby się raczej ku ludzkiemu wnętrzu. Tym razem to człowiek, jako dogłębnie zraniony dysponent sensów, starałby się wkomponować alfabet swoich cierpień w pismo otaczającej go natury. A ujmując to mniej metaforycznie, można by rzec, iż finalnym wynikiem autorefleksji, poczynionej

\footnotetext{
${ }^{13}$ Por. D. Laub, Zdarzenie bez świadka: prawda, świadectwo oraz ocalenie, przeł. T. Łysak, „Teksty Drugie” 2007, nr 5.

${ }^{14}$ Zob. D. Avey, R. Broomby, Człowiek, który wkradt się do Auschwitz, przeł. R. Palewicz, Insignis, Kraków 2011.

${ }^{15}$ Por. A. Ubertowska, Natura u kresu (ekocyd), „Teksty Drugie” 2013, nr 1-2.

${ }^{16}$ Człowiek, który wkradt siędo Auschwitz, zD. Avey’em rozm. M. Wójcik [online], http://on.interia. $\mathrm{pl} /$ historia/news-czlowiek-ktory-wkradl-sie-do-auschwitz,nId,450822 [dostęp 15.03.2017].

${ }^{17}$ To, rzecz jasna, aluzja do znanej formuły autorstwa Emmanuela Lévinasa.
} 
pod wpływem narzuconych przez historię ekstremalnych okoliczności, niejednokrotnie bywało głęboko zinterioryzowane przeświadczenie: wobec zgrozy tak niewyobrażalnych zbrodni, jak masowe egzekucje, czystki etniczne czy ludobójstwo, nieodwracalnie zmienić się musi także sposób, w jaki postrzegana jest natura. W wyniku tych przemian przyroda przestawałaby być neutralnym tłem dla „brudnych czynów” popełnionych przez człowieka, a stawałaby się istotnym „aktorem”, kimś, podkreślmy, kto czynnie uczestniczy w wojennym horrendum. Kimś, od kogo można i należałoby oczekiwać moralnej reakcji. Jeśli rzeczywiście w ten sposób uchylić antropocentryczną perspektywę, okaże się, że natura zaczęłaby się jawić z jednej strony jako zapomniana (ukryta) ofiara ludzkiej agresji, z drugiej - to raczej rzadszy wariant - jako oniemiały świadek niemoralnych ludzkich poczynań, świadek, którego głos siłą ludzkiej rzeczy musi być zapośredniczony. Można również wskazać relacje, w których obie role, ofiary i świadka, są ze sobą organicznie splecione, jak w przywołanej na wstępie tego studium wielogłosowej powieści-oratorium Swietłany Aleksijewicz. Oto fragment:

Pamiętam takie zdarzenie... Przyszliśmy do wsi, a tam pod lasem leżeli zabici partyzanci. Nie będę mówić, jak się nad nimi znęcali - serce by nie wytrzymało. Krajali ich po kawałku... Wypruli kiszki jak świniom... Leżą... A niedaleko pasą się konie. Widać, że to partyzanckie, nawet osiodłane. Może uciekły Niemcom i wróciły, a może ci już nie zdążyli ich zabrać - nie wiadomo. Daleko nie odeszły. Trawy jest dużo. Pomyślałam: „Jak ludzie mogli przy koniach robić coś takiego? Przy zwierzętach. Konie na nich patrzyły..."18.

Raz jeszcze warto podkreślić, że nieprzypadkowo to właśnie kobieca pamięć przechowała dla nas tego rodzaju wstrząsające obrazy - sceny, w obrębie których węzły ludzkiego cierpienia splatają się z krzywdą wyrządzoną zwierzętom, roślinom, krajobrazowi. Wojna, obóz koncentracyjny, Zagłada, widziane oczyma kobiet nie tylko otwierałyby przed nami ,inną wersję historii”, ale miałyby także - jak w jednym z wywiadów celnie zauważyła białoruska noblistka - inny zapach, inny kolor. Czy cechowałoby je również inne brzmienie? Jeśli na zasadzie swoistego negatywu do lagrowego „pejzażu dźwiękowego” zaliczyć także tony, których tak odczuwalnie zabrakło, wówczas właśnie w ten sposób zinterpretować by można milczenie ptaków, ciszę, o której tak często wspominały polskie więźniarki.

Przyglądając się z różnych stron zagadce lagrowego „nieba bez ptaków”, w pewnym momencie musimy postawić pytanie dotyczące stopnia (nieuchronnej?) konwencjonalizacji analizowanych przedstawień, tkwiącego w nich głęboko topicznego potencjału. Tak sformułowana wątpliwość przyczynić się musi do

\footnotetext{
${ }^{18}$ S. Aleksijewicz, dz. cyt., s. 147.
} 
istotnej reorientacji naszych poszukiwań, można bowiem spekulować, czy tym, co w istocie próbujemy poddać rekonstrukcji, są relacje pomiędzy światem ludzkim a pozaludzkim - uchwycone z perspektywy uwięzionych za drutami - czy też może jedynym, do czego mamy realny dostęp, jest sposób, w jaki owe relacje odcisnęły się w ruchomych ramach więźniarskiej pamięci. Albo, czego nie można przecież wykluczyć, pewna specyficzna forma projekcji, w wyniku której doszłoby do mimowolnego zniekształcenia zarejestrowanego w lagrowych relacjach obrazu rzeczywistości. Jeśli tak przestawić akcenty, należałoby zastanowić się, czy zdiagnozowana w obrębie części piśmiennictwa obozowego ornitologiczna próżnia funkcjonuje jako paradoksalny ślad obecności, odsłaniający przed czytelnikami widziany przez „pogrążonych” fragment świata, który, choć tak dogłębnie nierealny, był mimo wszystko światem rzeczywistym, czy może... Czy może raczej jest dokładnie na odwrót. Wówczas to, co zwykliśmy kwalifikować jako przejaw efektu mimetycznego, jako narracyjny ślad etycznej powinności dania jak najpełniejszego świadectwa prawdzie, częściowo ustąpiłoby miejsca szczególnego rodzaju (auto)iluzji, w wyniku której tak intrygujący nas milczący pejzaż więcej mówiłby (mówił milcząc) o wewnętrznym stanie zbiorowego podmiotu naszych narracji, niż o ich przedmiocie, świecie, który nie podlegałby „zawieszeniu”.

Dość nieoczekiwanie zatem pytanie o migotliwą obecność ornitofauny $\mathrm{w}$ piśmiennictwie lagrowym przekształcić się musi w element jednego z fundamentalnych sporów dotyczących literatury świadectwa jako narracyjnej całości. Unosząc wzrok wraz z więźniarkami kacetów, uważnie wpatrując się w burą płachtę nadoobozowego nieba - bo tym poniekąd byłaby nasza lektura, przeoczony przez autora Nadzorować $i$ karać wariant ,archeologii spojrzenia” - równocześnie zbliżalibyśmy się do tej cienkiej, ruchomej linii, oddzielającej to, co „faktyczne”, „obiektywne”, od tego, co pochodziłoby z wyraźnie odmiennego porządku ${ }^{19}$. Porządku, w obrębie którego ptak wiódłby podwójny literacki żywot: nie przestając być przedstawicielem uskrzydlonej gromady kręgowców, jednym z doprawdy niewielu zwierzęcych stworzeń, które dobrowolnie znalazłyby się w obozowej orbicie, jednocześnie odcisnąłby swój ślad jako symbol wartości, których lagrową społeczność brutalnie pozbawiono. Chodzi, rzecz jasna, o niczym nieograniczoną wolność, czy też o tak sugestywnie opisaną przez Gastona Bachelarda $^{20}$ swobodę w przemierzaniu przestrzeni i pokonywaniu wszelkiego rodzaju barier i granic, także tej najistotniejszej, nieprzekraczalnej, wytyczonej przez naelektryzowane druty.

\footnotetext{
${ }^{19}$ Przywołać w tym kontekście warto klasyczną rozprawę Haydena White'a. Zob. tenże, Realizm figuralny w literaturze świadectwa, przeł. E. Domańska, w: tenże, Proza historyczna, przeł. R. Borysławski [i in.], Kraków 2009.

${ }^{20}$ Zob. G. Bachelard, Poetyka skrzydel, przeł. A. Tatarkiewicz, w: tenże, Wyobraźnia poetycka. Wybór pism, przeł. H. Chudak, A. Tatarkiewicz, przedm. J. Błoński, Państwowy Instytut Wydawniczy, Warszawa 1975.
} 
Tym samym ptak dołączyłby do niemałej grupy zwierzęcych stworzeń, którym - w literaturze lagrowej i literaturze Zagłady (a może nawet w odwrotnej kolejności) - przyszło odgrywać szczególną i, w moim przekonaniu, niezwykle istotną rolę. $Z$ jednej strony, stanowiłyby one - niczym słynny Lanzmannowski zając $^{21}$ - nieosiągalny rewers kondycji uwięzionych w obozach koncentracyjnych, gettach, więzieniach ${ }^{22}, \mathrm{z}$ drugiej, właśnie $\mathrm{z}$ tego powodu, stawałyby się częścią magnetyzującego marzenia, fantazmatu, w obrębie którego stopniowo rozmywałyby się granice pomiędzy biologicznymi gatunkami. Zapis tego osobliwego zoomorficznego afektu, fantazji o jedynej formie ucieczki, jaką mogło zagwarantować porzucenie ludzkiego (żydowskiego) ciała i przedzierzgnięcie się w zwierzęcy organizm, uznać można za istotny mikrotopos obozowego i holokaustowego piśmiennictwa. Oto trzy wybrane przykłady, w dwóch z nich pojawi się ruchomy cień tak zajmujących mnie w tym studium (lagrowych) ptaków:

Zazdrościłam wówczas myszom i szczurom - one nie były tak bezradne jak my owej nocy na potwornym Umschlagu, kiedy czekaliśmy na pociąg do obozu zagłady i tortur! Myszy i szczury miały swoje nory, mogły ukryć się przed wrogiem i niebezpieczeństwem. A nam nie wolno było opuścić tych pokojów ani nawet wyjść do ustępu ${ }^{23}$.

Nieraz ponad obozem przeleciało kilka wróbli, czasem czajka, kwiląc, chwilę krążyła ponad naszymi głowami. Chore z tęsknoty czepiałyśmy się oczami ich skrzydeł, szepcząc z zazdrością: „Szczęśliwy ptaku!”24.

Tak sobie to projektowałyśmy, tak właśnie miało być, gdy było zupełnie inaczej, gdy niedzielny nasz spacer odbywał się pomiędzy blokami, piętnaście kroków tam, piętnaście kroków z powrotem, albo wzdłuż muru najeżonego drutami i tak nieprzebytego, że aż dziwnie było patrzeć, jak przelatują nad nim chmury i stada wron ${ }^{25}$.

\footnotetext{
${ }^{21}$ Nawiązuję tu do znanego fragmentu filmu Shoah. Więcej na ten temat pisałem w książce: „Dlaczego gesi krzyczały?”. Zwierzęta i Zagłada w literaturze polskiej XX i XXI wieku, Wydawnictwo Instytutu Badań Literackich, Warszawa 2016 (tu rozdz. Sarny w Birkenau).

22 Pewnym wariantem takiej autoidentyfikacji uwięzionych byłoby oświeceniowe z ducha porównywanie własnej kondycji do ptaków w... klatce, względnie do ptaków, które brutalnie pozbawiono daru lotu. „Człowiek w niewoli staje się jak ptak, któremu połamano skrzydła. Taki ptak najczęściej umiera", M. Rutkowska-Kurcyuszowa, Kamyki Dawida. Wspomnienia, Unia, Katowice 2005 , s. 147.

${ }^{23}$ H. Birenbaum, Nadzieja umiera ostatnia, Czytelnik, Warszawa 1988, s. 82.

${ }^{24}$ M. Plater-Skassa, Wspomnienia, w: Ponad ludzka miarę. Wspomnienia operowanych z Ravensbrück, wstęp W. Kiedrzyńska, Książka i Wiedza, Warszawa 1969, s. 369.

${ }^{25}$ Z. Romanowiczowa, Przejście przez Morze Czerwone, Państwowy Instytut Wydawniczy, Warszawa 1961, s. 83. Na marginesie powyższego cytatu warto zwrócić uwagę na istotną rolę, jaką motywy animalistyczne - w tym motyw braterstwa więźniów i zwierząt - odgrywają w lagrowej twórczości pisarki (kwestię tę podkreślił m.in. Arkadiusz Morawiec - zob. tenże, Zofia
} 
Kończąc z wolna pierwszą część swoich rozważań, w ramach której ptak chwiejnie grawitował pomiędzy realnym stworzeniem a kulturowym znakiem kierującym naszą uwagę ku jedynie częściowo zakamuflowanym treściom, odpowiedzieć powinienem na jeszcze jedno pytanie. W istocie przyszło mi zmierzyć się z kontrargumentem, który może, a nawet powinien pojawić się w tym momencie prowadzonego przeze mnie ornitologicznego ,śledztwa”. Słusznie można bowiem zapytać, czy jako wspólnota interpretacyjna, zespół badaczy, który podejmuje się lektury relacji z wydarzeń mających miejsce ponad siedem dekad temu, w ogóle dysponujemy instrumentarium, które pomogłoby nam zweryfikować niejasny status nurtującej nas figury ,nieba bez ptaków”. Ujmując to z mimetyczną prostolinijnością, wypadałoby spytać: „,były tam, czy ich nie było?”, a może - wbrew zasadzie tertium non datur - należałoby raczej rzec: „były tam, a jakoby ich nie było?”. Mimo wszystko spróbujmy podążyć tym rozmywającym się w powietrzu tropem.

\section{II. Życie ptaków w Auschwitz}

Zasygnalizowane przed momentem rozedrganie perspektywy pogłębi się jeszcze, gdy dokonamy istotnego przesunięcia, roszady w ramach Hilbergowskiego trójkąta. Myślę tym razem o pewnym odkryciu poczynionym w zbiorach Państwowego Muzeum Auschwitz-Birkenau w Oświęcimiu. Otóż w bibliotece tego wyjątkowego muzealnego przybytku natknąć się możemy na pewnego „białego kruka", co w tym wypadku rozumieć można nieomal literalnie. Mowa o rozprawie zatytułowanej Beobachtungen über die Vogelwelt von Auschwitz ${ }^{26}$, której autorem jest niejaki Günther Niethammer. Rzeczone studium opublikowane zostało w najciemniejszej fazie wojennej nocy, w 1942 roku - co samo w sobie zasługiwałoby zapewne na osobny komentarz - na łamach wiedeńskiego czasopisma naukowego „Annalen des Naturhistorischen Museums in Wien”. Niethammer, ceniony niemiecki ornitolog, przyszły przewodniczący Niemieckiego Stowarzyszenia Ornitologicznego, który w 1937 roku wstąpił do $\mathrm{SS}^{27}$, a podczas wojny

Romanowiczowa. Pisarka nie tylko emigracyjna, Wydawnictwo Uniwersytetu Łódzkiego, Łódź 2016, s. 87). W jednym z powstałych za drutami wierszy autorka wyzna, antycypując niejako słynną formułę Edgara Kupfera-Koberwitza: „Jakże mało się różnię od sarn i zajęcy / Moich braci strwożonych i sióstr biednych moich..." (taż, Jest we mnie..., w: Ravensbrück. Wiersze obozowe, red. W. Kiedrzyńska, Związek Bojowników o Wolność i Demokrację, Warszawa 1961, s. 36).

${ }^{26}$ G. Niethammer, Beobachtungen über die Vogelwelt von Auschwitz [online], http://www.zobodat.at/pdf/ANNA_52_0164-0199.pdf [dostęp: 15.03.2017]. Tym, co po latach uderza w trakcie lektury tej rozprawy, jest... specyficzna czcionka. Mowa o wielokrotnie powracających symbolach SS, zapisanych grafemicznym odpowiednikiem starogermańskiego pisma runicznego.

${ }^{27}$ Ten fragment biografii Niethammera referuję na podstawie bloga historycznego Adama Cyry. Zob. http://cyra.wblogu.pl/swiat-ptakow-w-auschwitz.html [dostęp: 15.03.2017]. Postać na- 
podjął służbę wartowniczą w esesmańskiej załodze KL Auschwitz, w przytoczonym artykule dzieli się wynikami badań terenowych, przeprowadzonych na terytorium kacetu i w jego bezpośrednim pobliżu. Dodajmy, że oficjalną zgodę na czasowe zwolnienie $\mathrm{z}$ wartowniczych obowiązków, by móc $\mathrm{w}$ pełni poświęcić się obserwacji okolicznego ptactwa, umundurowanemu ornitologowi wystawił komendant obozu, Rudolf Höß (za co zresztą autor nie omieszkał pisemnie podziękować na przechowywanym w muzeum egzemplarzu rozprawy). Nie można również wykluczyć, że to właśnie pod wpływem Niethammera wydany został Rozkaz specjalny komendantury, dotyczący między innymi zakazu odstrzału ptaków w obrębie obozu koncentracyjnego w Auschwitz i na terenach bezpośrednio z nim sąsiadujących. Ta rzeczywiście niezwykła historia zainspirowała współczesnego niemieckiego prozaika Arno Surminskiego, który na jej kanwie oparł z pewnych względów rozczarowującą niestety powieść Die Vogelwelt von Auschwitz (powieść ta, dopowiedzmy, kilka lat temu została przetłumaczona na język polski $)^{28}$.

Już sam fakt, że w naukowym artykule Niethammera wymienionych zostaje ponad sto gatunków ptaków - tak, to nie pomyłka, ponad sto gatunków (uprzedźmy, że nieco inaczej kwestia ta kształtuje się w powieściowym „odbiciu” owego studium), świadczyć może o tym, że Kotlina Oświęcimska, przestrzeń międzyrzecza, pobliże ujścia Soły do Wisły, a więc miejsce, gdzie Niemcy zdecydowali się usytuować swą najbardziej wydajną z fabryk śmierci, z punktu widzenia zawodowego ornitologa jawić się może bez mała jako ziemia obiecana ${ }^{29}$. Na pozór wyglądałoby więc, że wystarczy odwrócić perspektywę, powierzyć głos sprawcy (co oczywiście nie jest gestem etycznie obojętnym), który nie tylko dysponował nieporównywalną swobodą poruszania się, ale również wolny był od najbardziej elementarnych trosk, na jakie skazani byli więźniowie i więźniarki kacetu, by „niebo bez ptaków” z nagła wypełniło się ruchem skrzydeł.

Oczywiście, uwzględniając tak radykalną różnicę percepcji, równocześnie musimy mieć świadomość, że zbytnia generalizacja prowadzić może w naszym wypadku do mylnych wniosków. Innymi słowy: intensywność ,ż̇ycia ptaków w Auschwitz" nie musiała być i z pewnością nie była tożsama z równie bujnym życiem ptaków na Majdanku, w Ravensbrück czy - to dla nas chyba najistotniej-

zistowskiego badacza ptaków przypomniał także niedawno Stanisław Łubieński w eseju Koniec świata nad Kinkeimer See, w: tenże, Dwanaście srok za ogon, Wydawnictwo Czarne, Wołowiec 2016, s. 140.

${ }^{28}$ A. Surminski, Życie ptaków w Auschwitz, przeł. R. Załuska, posł. M Ossowski, Carpatia, Rzeszów 2011. Rec. B. Darska, Ptaki maja lepiej niż ludzie [online], http://bernadettadarska.blog. onet.pl/2012/03/13/ptaki-maja-lepiej-niz-ludzie-a-surminski-zycie-ptakow-w-auschwitz/ [dostęp: 15.03.2017].

${ }^{29}$ Dodajmy, że wymienione tereny Doliny Dolnej Soły, szczególnie cenne przyrodniczo i krajobrazowo, podlegają dziś ochronie jako obszar Natura 2000. Zob. Katalog obszarów Natura 2000 [online], http://obszary.natura2000.org.pl/index.php?s=obszar\&id=463 [dostęp: 15.03.2017]. 
szy kontrapunkt - w nieodległym Birkenau. Właśnie tak dychotomicznie kształtująca się przestrzeń, rozpięta pomiędzy pierwotnym obozowym kompleksem Auschwitz (KL Auschwitz I - Stammlager) a swoistą „blizną” po wsi Brzezinka, gdzie wkrótce miało powstać centrum masowej eksterminacji (Auschwitz II - Birkenau) $)^{30}$, posłużyła Surminskiemu za podwójne miejsce akcji przywoływanej przeze mnie powieści. Narracja ta - oparta na celowo rozmytych losach Niethammera (choć w strukturę powieści równocześnie wkomponowane zostały liczne cytaty z naukowej publikacji ornitologa) - ufundowana została na zwielokrotnionym kontraście: zapewne już samo zestawienie beztroskiego podglądania ptasich gniazd, podczas gdy za drutami giną miliony ludzkich istnień, stanowiłoby nieusuwalny dysonans, ale niemiecki prozaik zadbał o to, aby na tym nie wyczerpała się ta dysharmonijna logika. Właśnie temu efektowi służy wprowadzenie w powieści podwójnej perspektywy narracyjnej, obejmującej punkt widzenia umundurowanego badacza oraz jego polskiego pomocnika, byłego studenta Akademii Sztuk Pięknych, więźnia Marka Rogalskiego (postaci w pełni fikcyjnej), ale źródłem kontrastu, jak wspominałem, staje się również przestrzeń, w jakiej poruszają się w naukowej pogoni za ptactwem obydwaj mężczyźni. Nazwa, którą zwykliśmy wypowiadać jednym tchem: Auschwitz-Birkenau, zostaje tutaj rozbita, a to, co najistotniejsze - również w kontekście intrygującej nas zagadki „nieba bez ptaków” - dzieje się w obrębie „pomiędzy”, w przestrzeni wypełnionej przez dywiz.

By w pełni uświadomić sobie biegunową różnicę pomiędzy dwiema częściami lagrowego kompleksu (Auschwitz i Birkenau), różnicę nieredukowalną także z zaskakującej na pozór przyrodniczej perspektywy, raz jeszcze powinniśmy przywołać jego skomplikowane początki oraz ewolucję funkcji - od koncentracji do eksterminacji - jakiej ostatecznie miała być podporządkowana znaczna część obozowej infrastruktury. Podczas gdy „macierzysty” korpus obozu został ulokowany na terenie przedwojennych koszar Wojska Polskiego, w obszarze w widłach rzek Wisły i Soły - jak mogliśmy stwierdzić - z wielu względów wyjątkowo sprzyjającym bioróżnorodności, o tyle Birkenau, drugi obóz zespołu KL Auschwitz, którego budowę rozpoczęto na rozkaz Heinricha Himmlera jesienią 1941 roku, powstawał w zgoła odmiennych warunkach. Właśnie niekończący się proces powstawania, coś, co można by chyba określić jako permanentne in statu nascendi, zaważył niejako na charakterze tego upiornego miejsca oraz na trybie ludzkiej w nim obecności. Obecności, którą moglibyśmy nazwać najdosłowniej pojmowanym byciem-ku-śmierci, gdyby nie niepodważalny fakt, że - jak zgodnie twierdzą filozofowie - w niemieckich obozach zagłady istota śmierci została

\footnotetext{
${ }^{30}$ Więcej na temat genezy obozu: L. Rees, Auschwitz. Naziści i „ostateczne rozwiąanie”, przeł. P. Stachura, wstęp W. Bartoszewski, Prószyński i S-ka, Warszawa 2009; Auschwitz 1940-1945. Węzłowe zagadnienia z dziejów obozu, t. 1-5, red. W. Długoborski, F. Piper, Wydawnictwo Państwowego Muzeum Auschwitz-Birkenau, Oświęcim-Brzezinka 1995.
} 
bezpowrotnie wykluczona, w wyniku czego człowiek nie umierał, a jeszcze za życia (jeśli mimo wszystko przystaniemy na to określenie) stopniowo przeobrażał się $\mathrm{w}$ trupa, przyszły przedmiot utylizacji ${ }^{31}$. Birkenau, którego metonimią w wielu wspomnieniach więźniarek nieprzypadkowo stało się błoto, niekończące się morze błota ${ }^{32}$, jawiłoby się zatem jako miejsce wrogie wszelkim formom życia. Dotyczyłoby to również form istnienia innych niż ludzkie. Roślin, zwierząt, w tym również ptaków. Oddajmy głos autorce najbardziej znanej relacji z tamtego miejsca:

W roku 1942 Birkenau (tak zwany Oświęcim II) to pole bagniste, ogrodzone drutami pod wysokim napięciem. Nie ma żadnych dróg, żadnych ścieżek pomiędzy blokami, cały lager pozbawiony jest wody, a równocześnie (do końca zresztą) jakichkolwiek ścieków. Wszelkie brudy, odchody, odpadki leżą cuchnąc i gnijąc. Żaden ptak nie pokazuje się nisko nad Birkenau, choć w ciągu wielogodzinnych apelów więźniowie mają czas wypatrywać. Powodowane węchem czy instynktem ptaki omijają to miejsce. Birkenau oficjalnie nie istnieje. Nie jest wymieniane nigdy w adresie. Sposób budowania tego obozu świadczy, że nie zamierzano tu przetrzymywać ludzi dłużej. Jest to pewnego rodzaju poczekalnia przedkrematoryjna, obliczona na dwadzieścia do trzydziestu tysięcy ludzi ${ }^{33}$.

Czyż można dziwić się ptakom? Jeśli pomiędzy karty Dymów nad Birkenau wkomponujemy fotografie tego obozowego kompleksu, fotografie - a jakże - nierzadko wykonane z lotu ptaka, być może jeszcze wyraziściej uzmysłowimy sobie, rzecz jasna o ile uda nam się stłumić antropocentryczne odruchy, że nie były to okolice, w których, będąc przedstawicielem tej gromady zwierząt, chciałoby się uwić gniazdo. Czy choćby tylko na moment przerwać lot w celu spoczynku lub poszukiwania pokarmu. Pusta płaszczyzna przestrzeni wypełniona przez ułożone z okrutną precyzją liczne prostopadłościany budynków. Baraki, warsztaty, latryny, magazyny mienia więźniarskiego, krematoria. Antypejzaż mogący skojarzyć się z fragmentem słynnego utworu Czesława Miłosza: „Jest już tylko piaszczysta, zdeptana, z jednym drzewem bez liści Ziemia" ${ }^{34}$. A przecież powinniśmy pamiętać o czymś jeszcze, o czymś, czego z oczywistych względów nie był w stanie uchwycić obiektyw kamery czy aparatu. Obozowe powietrze! Sposób,

${ }^{31}$ Zob. G. Agamben, Co zostaje z Auschwitz. Archiwum i świadek (Homo sacer III), przeł. S. Królak, Wydawnictwo Sic!, Warszawa 2008, s. 76.

${ }^{32}$ A. Kłos, Znikająca pamięć Birkenau. Opowieść o sile przyrody, „Opposite” [online], nr 3, http://opposite.uni.wroc.pl/2012/klos.htm [dostęp: 15.03.2017].

${ }^{33}$ S. Szmaglewska, Dymy nad Birkenau, Czytelnik, Warszawa 1975, s. 15.

${ }^{34}$ C. Miłosz, Biedny chrześcijanin patrzy na getto, w: tenże, Wiersze, Wydawnictwo Literackie, Kraków-Wrocław 1985, t. 1, s. 133. 
w jaki odcisnęło się ono w więźniarskiej pamięci, jego zapach ${ }^{35}$, konsystencja, a nawet smak, z pewnością zasługiwałyby na osobne studium. Tu przytoczmy zaledwie jeden fragment, tym razem dotyczący innego obozu, w którym również dzień i noc rozgrzane były krematoryjne piece:

Do czarnego, kłębiącego się dymu, który bezustannie wydobywa się z komina krematorium obok obozowego więzienia, dochodzą jeszcze szerokie, ciągnące nad ziemią cuchnące tumany. Pochodzą one z płonących za krematorium rowów, do których specjalne komando znosi zagazowane więźniarki, kiedy już cyklon B o osłabionym działaniu ostatecznie zdławi im oddech ${ }^{36}$.

Po tym krótkim historycznym ekskursie wróćmy do obserwacji poczynionych przez Günthera Niethammera i jego powieściowe alter ego, Hansa Grotego, wraz z nieodłącznym polskim pomocnikiem, dla którego ta szczególna służba miała być (ale niestety nie była) jedyną szansą na opuszczenie obozowej ,klatki”. Jak wyglądałby zatem kacet widziany okiem (uzbrojonym w lornetkę) profesjonalnego ornitologa? Powtórzmy jeden z wcześniejszych wniosków, z gatunku tych, które zaliczyć by należało do co najmniej nieoczywistych: otóż, gdy mówimy o KL Auschwitz I i jego pobliżu na podstawie wyników badań zreferowanych w ornitologicznym studium, bez posądzenia o przesadę rzec można, iż było to omalże ptasie eldorado, przestrzeń, ,gdzie - pomimo wszystko! - śpiewają ptaki”. By wyjaśnić ów zagadkowy na pozór stan, powierzmy głos naukowcowi:

Przyczyną bogatej populacji ptaków w obrębie obozu może być brak naturalnych wrogów. Psy i koty nie mają tu dostępu. Wartownicy zabijają na miejscu bezpańskie zwierzęta. Tylko ptaki drapieżne, głównie myszołowy i sroki, przyczyniają się do pewnego wyniszczania populacji ptaków ${ }^{37}$.

Gdy powyższe konstatacje skonfrontujemy z przywoływanym w tej części rozważań Rozkazem specjalnym komendantury, może się okazać, że wielowymiarową mapę napięć i kontrastów składających się na opowieść o, ,życiu ptaków w Auschwitz" uzupełnić by należało o kolejne ogniwo. Troska, z jaką obozowe

${ }^{35}$ Wbrew potocznym mniemaniom - co intuicyjnie wyczuła Szmaglewska - ptaki mają dobrze rozwinięty zmysł węchu. Zob. S. Steiger, A.E. Fidler, M. Valcu, B. Kempenaers, Avian olfactory receptor gene repertoires: evidence for a well-developed sense of smell in birds?, „Proceedings of the Royal Society B" [online] 2008, vol. 275, issue 1649; http://rspb.royalsocietypublishing.org/ content/275/1649/2309 [dostęp: 15.03.2017].

${ }^{36}$ A. Lundholm, Wrota piekiet. Ravensbrück, przeł. E. Czerwiakowska, posł. J. Szymoniczek, Ośrodek Karta, Warszawa 2014, s. 248. Tu tylko zasygnalizuję, że wymieniona relacja obfituje w różnego rodzaju ornitologiczne wątki, które z pewnością zasługiwałyby na osobną interpretację.

${ }^{37}$ A. Surminski, dz. cyt., s. 117. Jako wyimek z rozprawy Niethammera fragment ów został w powieści zapisany kursywą. 
władze odnosiły się do chronionych gatunków zwierząt (ptaków), płynnie wpisywałaby się w całość koncepcji biowładzy przyjętej przez reżim NSDAP, koncepcji, w obrębie której zakaz okrucieństwa wobec fauny ${ }^{38}$ rażąco kontrastowałby ze sposobem traktowania „niższych rasowo” ludzkich ofiar.

Jak się jednak za moment okaże, w przyrodzie nic nie dzieje się w pełnej izolacji, w wyniku czego ostrze nazistowskiej polityki eksterminacyjnej, wymierzonej w ludzkie populacje, przede wszystkim w naród żydowski, boleśnie dotknie również ekosystemu jako zintegrowanej całości, w tym jego ptasich przedstawicieli. Miejscem, w którym ów niepokojący proces ujawni się z całą mocą, będą tereny Birkenau (dawnej wsi Brzezinka). Jakkolwiek dwuznacznie by to nie zabrzmiało, wiadomość o tym, że władze SS zdecydowały się ulokować drugą część obozu na terytorium wioski, mającej wkrótce całkowicie zniknąć z powierzchni ziemi, z perspektywy profesjonalnego badacza jawić się musiała jako niepowtarzalna szansa, prawdziwe wyzwanie. Niemiecki protagonista powieści Surminskiego podejmuje zatem plan, „żeby zbadać obecny stan [przed wzniesieniem kompleksu Birkenau] ptactwa we wsi i w okolicy, a potem obserwować zmiany w trakcie prac budowlanych, by w końcu zarejestrować ich zasób po zakończeniu budowy"39. Wnioski płynące z tak pomyślanego komparatystycznego eksperymentu są chyba nietrudne do przewidzenia. Po trosze dałoby się je wydedukować z tęsknego spojrzenia więźniów i więźniarek, uchwyconego przez Sewerynę Szmaglewską. ,Żaden ptak nie pokazuje się nisko nad Birkenau...”. I rzeczywiście, tym, co uda się w trakcie szczegółowych badań skonstatować umundurowanemu biologowi, będzie stopniowy, konsekwentny ubytek ornitofauny, aż do jej całkowitego zaniku, z jednym, acz nader znamiennym, wyjątkiem.

Zanim wyjawię, jaki to ptasi gatunek upodobał sobie miejsce masowej zbrodni, ludobójstwa popełnionego przez hitlerowców, kilka słów powinienem poświęcić złożonej intertekstualnej relacji pomiędzy analizowaną tu współczesną powieścią a jej (pozornym?) naukowym analogonem, ornitologiczną rozprawą Niethammera. Rzecz jasna nawet na moment nie powinniśmy zapominać, że dziedzina literackości rządzi się własnymi prawami i nawet jeśli aspiruje do realizmu - tak jak dzieje się to w interesującym nas przypadku - trudno byłoby wymagać od niej iście naukowej precyzji. Być może był to właśnie jeden z powodów, dla których świadom podjętego ryzyka niemiecki pisarz $\mathrm{w}$ trakcie prac nad powieścią korzystał z pomocy naukowego konsultanta (biologa), co z pewnością pomogło mu uniknąć rażących pomyłek (takich choćby jak obraz czajek przysiadających na obozowych drutach). Atoli potrafimy wskazać miejsce, gdzie ścieżki

${ }^{38}$ Więcej na ten temat: L. Ferry, Nowy ład ekologiczny: drzewo, zwierze i czlowiek, przeł. H. Miś i A. Miś, Scholar, Warszawa 1995 (tu rozdz. Ekologia nazistowska: ustawy z listopada 1933, lipca 1934 i czerwca 1935 roku). Zob. również: D. Heintz, Tierschutz im Dritten Reich: im neuen Reich darf es keine Tierquälerei mehr geben, Wara, Müllheim 2008.

${ }^{39}$ A. Surminski, dz. cyt., s. 80-81. 
prozaika i naukowca świadomie i bezpowrotnie się rozchodzą. Dotyczyłoby to właśnie ptasich „rezydentów” Birkenau, jedynych uskrzydlonych stworzeń, których - wedle pisarza raczej niż ornitologa - nie odstraszały gęste krematoryjne dymy. Tymi ptakami były wrony ${ }^{40}$, wyrazisty leitmotiv narracji Surminskiego. Cień jednego z tych krukowatych (choć patrząc na sylwetkę równie dobrze mógł to być gawron) odcisnął się na okładce polskiej edycji utworu ${ }^{41}$.

By zrozumieć szczególną pozycję reprezentantów tego gatunku w obrębie świata przedstawionego powieści, powinniśmy uważnie przyjrzeć się kontekstom, w jakich wronom przyszło występować. Dopiero wówczas w pełni ujawni się ich podwójny, a może nawet potrójny status. Polegałby on na swoistym zwielokrotnieniu konturów, w wyniku którego ptaki, nie przestając wykazywać pewnych cech upodmiotowionych istot (celne pisarskie obserwacje dotyczące miejsc, w których wrony żerują, czy sposobów, w jaki to czynią), równocześnie funkcjonowałyby jako głęboko w kulturze osadzony znak, symbol o zdecydowanie pejoratywnym nacechowaniu ${ }^{42}$. Można więc rzec, iż niemiecki prozaik, któremu najwyraźniej bardzo zależało na współobecności obu tych rejestrów, dokonuje swego rodzaju regresywnej inwersji: w przeciwieństwie do wielu współczesnych narracji zwierzęcych konstruuje bowiem taki obraz, w obrębie którego to, co symboliczne, wyraźnie prześwituje spod realnego, innymi słowy, to żywe stworzenie, z krwi, kości i piór, w zajmującej nas powieści nierzadko staje się maską mającą skrywać nietrudne do rozszyfrowania treści.

Dokąd by zatem wiodła nić wewnątrzpowieściowej ptasiej symboliki? Jak dobrze pamiętamy, wronom, a w wyższym może nawet stopniu blisko spokrewnionym z nimi krukom, przypadła w europejskiej kulturze rola dość niewdzięczna: zwykło się je kojarzyć ze śmiercią, wojną, epidemiami ${ }^{43}$, do czego niewątpliwie przyczyniły się ich kulinarne obyczaje. Na przestrzeni dziejów wrony i kruki z pewnością niejeden raz widziane były na pobojowiskach, cmentarzach,

${ }^{40}$ Dotyczyć to mogło również innych obozów. Na krukowate, jako na jedyne ptaki pojawiające się w polu widzenia (i słyszenia) więźniarek z Majdanka, w swoich wspomnieniach wskazała Danuta Brzosko-Mędryk. „Czekamy na słowo «ab» jak na zwykłe «won», ale słychać tylko krakanie kruków - jedynych ptaków, które szukają tu ścierwa”, D. Brzosko-Mędryk, dz. cyt., s. 119.

${ }^{41}$ A swoją drogą jest to jeden z ulubionych konceptów, reprodukowanych aż do granic plagiatu, z którym zetknąc się możemy w zaskakująco licznej grupie publikacji o tematyce obozowej. Na wizerunek ptaków siedzących na kolczastych drutach obozów natkniemy się zatem na okładkach następujących książek (to z pewnością nie wszystkie przykłady) - L. Wyszczelski, Jeńcy wojny polsko-rosyjskiej 1919-1920, Bellona, Warszawa 2014; V.E. Frankl, Człowiek w poszukiwaniu sensu, przeł. A. Wolnicka, Wydawnictwo Czarna Owca, Warszawa 2015; S. Helm, If this a woman? Inside Ravensbrück: Hitler's Concentration Camp for Women, Abacus, London 2015; Z. Posmysz, Wakacje nad Adriatykiem, Czytelnik, Kraków 2017.

42 Dodajmy, że na wielopiętrową metaforykę wron w powieści Surminskiego uwagę zwrócił również autor Posłowia, Mirosław Ossowski. Zob. A. Surminski, dz. cyt. s. 186.

${ }^{43}$ Zob. W. Kopaliński, Stownik mitów i tradycji kultury, Państwowy Instytut Wydawniczy, Warszawa 1985, s. 549. 
miejscach, gdzie składowano niepochowane zwłoki. Czyż należy dodawać, że pojawiały się tam w celu pożywienia się ciałem poległych lub zmarłych w wyniku zarazy? Echo tych niemiłych ludzkiemu sercu międzygatunkowych relacji, polskiemu czytelnikowi tak dobrze znanych choćby z powstańczej prozy Stefana Żeromskiego, przeniknęło również w głąb lagrowej powieści współczesnego niemieckiego prozaika (choć równocześnie warto podkreślić, że pisarz podjął przynajmniej jedną próbę reinterpretacji kulturowego wizerunku tak negatywnie portretowanych ptaków ${ }^{44}$. Po tym, jak ludzkie popioły wypełnią okoliczne stawy, w momencie, gdy na skutek rozkazów obozowej komendantury zostanie rozerwana wielosetletnia więź pomiędzy ziemią a uprawiającymi ją rolnikami, Hans Grote zanotuje w swoim notatniku: „Oprócz wron nie ma ptaków w Brzezince”"45, a przyczyna, dla której tak tłumnie zlatywałyby pomiędzy kolczaste druty, jak łatwo się domyślić, niczym nie różniła się od ich średniowiecznych antenatów. W jednym przypadku analogia pomiędzy współczesnością a wiekami średnimi wręcz się narzuca:

Gdy rankiem Marek wyglądał z bloku, widział przed sobą plac apelowy. Najczęściej był pusty, czasem szubienica czekała w gotowości do pracy. Można ją było przesuwać. Gdy plac był potrzebny na uroczyste defilady lub koncerty, usuwano okropne narzędzie śmierci. Początkowy zwyczaj, że powieszony godzinami wisiał na stryczku, jak to Grote mawial - dla odstraszenia, został zniesiony po tym, jak wrony obsiadły wisielca i wyrywały kawałki jego ciała. Od tej pory kazali zanosić umarłych do krematorium, zanim jeszcze zdążyli ostygnąc ${ }^{46}$.

Wpatrując się w tę powieściową scenę, a właściwie przełamując odruch nakazujący odwrócić wzrok, przypomnieć sobie możemy jedne z najbardziej drastycznych kadrów w historii kina: fragment filmu Lecha Majewskiego Mtyn $i$ krzyż, w którym również główną rolę przyszło odegrać skazańcowi i towarzyszącym mu do samego końca (a nawet dłużej) padlinożernym ptakom. A pozostając w kręgu malarskich skojarzeń (wszak film Majewskiego wyrósł z dzieła Pietera Bruegla starszego), przywołać moglibyśmy jeszcze jedno dzieło - Apoteozę wojny Wasilija Wierieszczagina. Piramida ludzkich czaszek, gromadzące się wokół niej kruki, w tle pusty horyzont z kikutami uschniętych drzew. Ostatnia część dedykacji, jaką malarz umieścił na ramie obrazu: „Wszystkim wielkim zdobywcom, minionym, współczesnym i przyszłym", pozwala na rozpięcie historycznego mostu pomiędzy walkami w Turkiestanie, w których za młodu uczest-

44 „Kruk krukowi oka nie wykole, pomyślał Marek. Czy to możliwe, żeby w międzyrzeczu zebrały się wrony z całej Polski, by zobaczyć co dzieje się w Brzezince? Można by też pomyśleć, że to kondukt żałobny, ubrani na czarno żałobnicy przybyli na pogrzeb", A. Surminski, dz. cyt. s. 145.

45 Tamże, s. 91.

${ }^{46}$ Tamże, s. 64. 
niczył artysta, a tym, co miało się wydarzyć za drutami XX-wiecznych obozów koncentracyjnych, rzecz jasna, nie tylko niemieckich.

Puentując powoli wątek powieściowych wron z Birkenau, ptaków, które polskiemu odbiorcy automatycznie kojarzyć się mogą z nazizmem (jako pogardliwa nazwa godła hitlerowskiej Rzeszy, dodać również można, że mianem wron polskie więźniarki z Ravensbrück określały terroryzujące je niemieckie strażniczki) ${ }^{47}$, dopowiedzieć powinniśmy, że miały one w przestrzeni obozu swoich naziemnych „sobowtórów”. Gdy w trakcie badań porównawczych Grote spróbuje zweryfikować, czy ptaki zaadaptowały się na terenie nowo powstałego „obozu pokazowego”, jaki wyrósł w okolicy wsi Brzezinka, natknie się na następujące dictum: „U nas są tylko wrony. [...] One panują w powietrzu, a szczury ${ }^{48}$ na ziemi’"49. Tym, co połączyłoby oba gatunki, względnie sprawiło, że przyszło im ze sobą rywalizować, były podobne żywieniowe nawyki, a co za tym idzie - to samo miejsce żeru, doły spaleniskowe szczelnie wypełnione przez usypisko martwych ludzkich ciał.

\section{Post fa(c)tum. Ptasie powroty}

Zgodnie z okulocentryczną poetyką mojego studium, którego jednym z głównych celów była próba „,archeologicznej” rekonstrukcji sposobu, w jaki więźniarki i więźniowie postrzegali ptaki, chciałbym już na sam koniec tych rozważań przywołać jeszcze jeden kadr. Lagrową scenę, w której ptactwu przyszło odegrać niebagatelną rolę. Choć wyodrębniony przeze mnie fragment, wyimek z prozy Zofii Posmysz dotyczy miejsca, któremu mieliśmy okazję dokładnie przyglądać się przez pryzmat dokumentarnej narracji Szmaglewskiej czy na poły fikcjonalnej powieści Surminskiego - mowa o obozowym kompleksie Auschwitz-Birkenau - tym razem nic nie będzie już takie samo. I to nie tylko w wyniku niepodważalnego faktu, że przedstawione wydarzenia dziać się będą wiele lat po zakończeniu wojny i wyzwoleniu obozów. Scena, którą pragnę przywołać, z pewnych względów

\footnotetext{
${ }^{47}$ Źródłem owego określenia był ubiór SS-manek: nosiły one na mundurach czarne, spięte pod szyją peleryny z kapturami. Zob. J. Fabierkiewicz-Szyrkowa, dz. cyt. s. 78.

${ }^{48}$ Lagrowym szczurom jako szczególnemu toposowi wielu narracji wspomnieniowych warto byłoby poświęcić osobne studium. Tu wymieńmy jeden przykład: „I wtedy to. Ból w palcu u nogi, jak wbicie igły. Szczur. Zwabiony nieruchomością ciała, przyszedł na żer. Krzyk więźnie w gardle. Szarpnięcie stopą, bezskuteczne. Zwierzę jest za ciężkie. Odczuło jednak impuls i samo zsunęło się na siennik. Teraz patrzy. Wąsy sztywne jak druciki i paciorki oczu. Inteligentne, badawcze spojrzenie. Podciągnąc derkę na twarz. Żeby choć tyle zdołać... Wtedy widzę - odchodzi. Nie smyrga, jak to one, w błyskawicznych susach, ale oddala się bez pośpiechu, przycupując raz po razie, gotowe w każdej chwili wrócić. Gdy tylko żer znieruchomieje ostatecznie", Z. Posmysz, Ten sam doktor M..., s. 226.

${ }^{49}$ A. Surminski, dz. cyt., s. 143.
} 
stanowi zwielokrotniony negatyw większości obozowych relacji. Jak pamiętamy, ich narratorki i narratorzy tęsknie wpatrując się w rozmywający się ptasi profil, mogliby w istocie przywołać wersy jednej ze wschodniosłowiańskich pieśni ludowych:

Gdybym tylko miał skrzydła,

Wzniósłbym się do nieba,

W chmury,

Gdzie nie ma bólu i $\mathrm{kar}^{50}$.

Mimo że protagonistka Wakacji nad Adriatykiem pasmo „bólu i kar” dawno ma już za sobą, okazuje się, że to tylko pozory. I że powrót do poobozowej rzeczywistości jest czymś nad wyraz trudnym, jeśli w ogóle możliwym do osiągnięcia. Nieznana magnetyczna siła nie tylko nie pozwala bohaterce oddalić się (mentalnie) od obozu, ale nakazuje jej wręcz coś dokładnie odwrotnego. Jak za moment zobaczymy, w drodze, jaką pokona była więźniarka, towarzyszyć jej będzie ktoś jeszcze. One również wróciły.

I oto ona przede mną, ta jedyna na całym świecie brama wzorem wszystkich bram powitalnych zwieńczona łukiem z ową zastanawiającą pochwałą pracy, a przed bramą, aby wszystko było jak ongiś, aby spełniła się wizja, stał człowiek, którego wysoką, z lekka przygarbioną postać zapamiętywał każdy, kto przekraczał bramę. Stał i wyglądał na drogę. Jego wyraźniejące rysy nie były mi nie znane, a jednak tchnęło z nich czymś obcym, co zatrzymało i słowa na wargach, i kroki. Granatowy beret na siwych kędziorach włosów, mimo iż noszony sposobem mycki niepokoił i podważał ufną pewność towarzyszącą mi do chwili, gdy pociąg ruszył z dworca. Staliśmy naprzeciw siebie milcząc i przyglądając się sobie, jak gdyby w oczekiwaniu, które odezwie się pierwsze, a nad nami świeciło gorące słońce i w ciszy takiej, jaka bywa na cmentarzach wiosną, opętańczo śpiewały ptaki. Powiedziałam wreszcie: „Ptaki śpiewają”, a on odrzekł: „Tak, nie było ich tutaj przedtem”, jego rysy złagodniały, gdy dodał: „Tyś także stąd, poznaję. Byłaś w magazynie”51.

\section{Bibliografia}

Agamben Giorgio, Co zostaje z Auschwitz. Archiwum i świadek (Homo sacer III), przeł. Sławomir Królak, Wydawnictwo Sic!, Warszawa 2008.

Aleksijewicz Swietłana, Wojna nie ma w sobie nic z kobiety, przeł. Jerzy Czech, Wydawnictwo Czarne, Wołowiec 2015.

${ }^{50}$ T. Snyder, Skrwawione ziemie. Europa między Hitlerem a Stalinem, przeł. B. Pietrzyk, Świat Książki, Warszawa 2015, s. 203-204.

${ }^{51}$ Z. Posmysz, Wakacje nad Adriatykiem, s. 236. 
Auschwitz 1940-1945. Węzłowe zagadnienia z dziejów obozu, t. 1-5, red. Wacław Długoborski, Franciszek Piper, Wydawnictwo Państwowego Muzeum Auschwitz-Birkenau, Oświęcim-Brzezinka 1995.

Avey Denis, Broomby Rob, Człowiek, który wkradt się do Auschwitz, przeł. Roman Palewicz, Insignis, Kraków 2011.

Bachelard Gaston, Wyobraźnia poetycka. Wybór pism, przeł. Henryk Chudak, Anna Tatarkiewicz, przedm. Jan Błoński, Państwowy Instytut Wydawniczy, Warszawa 1975.

Baudrillard Jean, Spisek sztuki, przedm. Sylvère Lotringer, przeł. Sławomir Królak, Wydawnictwo Sic!, Warszawa 2006.

Birenbaum Halina, Nadzieja umiera ostatnia, Czytelnik, Warszawa 1988.

Brzosko-Mędryk Danuta, Niebo bez ptaków, Wydawnictwo Ministerstwa Obrony Narodowej, Warszawa 1969.

Buryła Sławomir, Monografia po latach, „Teksty Drugie” 2009, nr 5, s. 100-105.

Buryła Sławomir, Pociagi śmierci - kilka uwag o konstrukcji hasła słownikowego, „Narracje o Zagładzie" 2016, nr 2, s. 63-71.

Buryła Sławomir, Tematy (nie)opisane, Universitas, Kraków 2013.

Buryła Sławomir, Wokół Zagłady. Szkice o literaturze Holokaustu, Universitas, Kraków 2016.

Cyra Adam [blog online], http://cyra.wblogu.pl/swiat-ptakow-w-auschwitz.html [dostęp: 15.03.2017].

Człowiek, który wkradt się do Auschwitz, z D. Avey’em rozm. M. Wójcik [online], http://on.interia. $\mathrm{pl} /$ historia/news-czlowiek-ktory-wkradl-sie-do-auschwitz,nId,450822 [dostęp 15.03.2017].

Darska Bernadetta, Ptaki mają lepiej niż ludzie [online], http://bernadettadarska.blog.onet.pl/2012 /03/13/ptaki-maja-lepiej-niz-ludzie-a-surminski-zycie-ptakow-w-auschwitz/ [dostęp: 15.03.2017].

Fabierkiewicz-Szyrkowa Janina, Gdzie nie śpiewały ptaki, Książka i Wiedza, Warszawa 1972.

Ferry Luc, Nowy ład ekologiczny: drzewo, zwierzę i człowiek, przeł. Hanna Miś i Andrzej Miś, Scholar, Warszawa 1995.

Frankl Viktor E., Czlowiek w poszukiwaniu sensu, przeł. Aleksandra Wolnicka, Wydawnictwo Czarna Owca, Warszawa 2015.

Greasley Horace, Czy w piekle ptaki nadal śpiewają? Prawdziwa historia człowieka, który stawit czoła nazistom. Wszystko z miłości do kobiety, przeł. Olga Kwiecień, Editio, Gliwice 2015.

Heintz Daniel, Tierschutz im Dritten Reich: im neuen Reich darf es keine Tierquälerei mehr geben, Wara, Müllheim 2008.

Helm Sarah, If this a woman? Inside Ravensbrück: Hitler's Concentration Camp for Women, Abacus, London 2015.

Kasia Jan, Tam, gdzie nie śpiewaja ptaki [online], http://www.polskieradio.pl/9/325/Artykul/ 219711,Tam-gdzie-nie-spiewaja-ptaki-Reportaz-Jana-Kasi [dostęp: 15.03.2017].

Katalog obszarów Natura 2000 [online], http://obszary.natura2000.org.pl/index.php?s=obszar\&id=463 [dostęp: 15.03.2017].

Kłos Agnieszka, Znikajaca pamięć Birkenau. Opowieść o sile przyrody, „Opposite” [online], nr 3, http://opposite.uni.wroc.pl/2012/klos.htm [dostęp: 15.03.2017].

Kopaliński Władysław, Słownik mitów i tradycji kultury, Państwowy Instytut Wydawniczy, Warszawa 1985.

Krupiński Piotr, ,Dlaczego gęsi krzyczały?”. Zwierzęta i Zagłada w literaturze polskiej XX i XXI wieku, Wydawnictwo Instytutu Badań Literackich, Warszawa 2016.

Laub Dori, Zdarzenie bez świadka: prawda, świadectwo oraz ocalenie, przeł. T. Łysak, „Teksty Drugie" 2007, nr 5, s. 118-130. 
Lundholm Anja, Wrota piekiet. Ravensbrück, przeł. Ewa Czerwiakowska, posł. Joanna Szymoniczek, Ośrodek Karta, Warszawa 2014.

Łubieński Stanisław, Dwanaście srok za ogon, Wydawnictwo Czarne, Wołowiec 2016.

Makowski Jarosław, Czy po Auschwitz da się jeszcze pisać wiersze? [online], http://makowski.blog. polityka.pl/2015/01/27/czy-po-auschwitz-da-sie-jeszcze-pisac-wiersze/ [dostęp: 15.03.2017].

Miłosz Czesław, Wiersze, Wydawnictwo Literackie, Kraków-Wrocław 1985, t. 1.

Morawiec Arkadiusz, Zofia Romanowiczowa. Pisarka nie tylko emigracyjna, Wydawnictwo Uniwersytetu Łódzkiego, Łódź 2016.

„Narracje o Zagładzie” 2016, nr 2: Topika zagłady.

Niethammer Günther, Beobachtungen über die Vogelwelt von Auschwitz, „Annalen des Naturhistorischen Museums in Wien" [online] 1942, http://www.zobodat.at/pdf/ANNA_52_01640199.pdf [dostęp: 15.03.2017].

Pawletko Beata, Blokada Leningradu i jej reprezentacje w świetle innych doświadczeń granicznych, „Śląsk” - Stowarzyszenie Inicjatyw Wydawniczych, Katowice 2016.

Plater-Skassa Maria, Wspomnienia, w: Ponad ludzka miarę. Wspomnienia operowanych z Ravensbrück, wstęp Wanda Kiedrzyńska, Książka i Wiedza, Warszawa 1969, s. 330-379.

Posmysz Zofia, Ten sam doktor M, Iskry, Warszawa 1981.

Posmysz Zofia, Wakacje nad Adriatykiem, Czytelnik, Warszawa 1970.

Ravensbrück. Wiersze obozowe, red. Wanda Kiedrzyńska, Związek Bojowników o Wolność i Demokrację, Warszawa 1961.

Rees Laurence, Auschwitz. Naziści i „,ostateczne rozwiąanie”, przeł. Paweł Stachura, wstęp Władysław Bartoszewski, Prószyński i S-ka, Warszawa 2009.

Romanowiczowa Zofia, Przejście przez Morze Czerwone, Państwowy Instytut Wydawniczy, Warszawa 1961.

Rutkowska-Kurcyuszowa Maria, Kamyki Dawida. Wspomnienia, Unia, Katowice 2005.

Snyder Timothy, Skrwawione ziemie. Europa między Hitlerem a Stalinem, przeł. Bartłomiej Pietrzyk, Świat Książki, Warszawa 2015.

Steiger Silke, Fidler Andrew E., Valcu Mihai, Kempenaers Bart, Avian olfactory receptor gene repertoires: evidence for a well-developed sense of smell in birds?, „Proceedings of the Royal Society B" [online] 2008, vol. 275, issue 1649, s. 2309-2317, http://rspb.royalsocietypublishing.org/content/275/1649/2309 [dostęp: 15.03.2017].

Surminski Arno, Życie ptaków w Auschwitz, przeł. Renata Załuska, posł. Mirosław Ossowski, Carpatia, Rzeszów 2011.

Szmaglewska Seweryna, Dymy nad Birkenau, Czytelnik, Warszawa 1975.

Ślady Holokaustu w imaginarium kultury polskiej, red. Justyna Kowalska-Leder [i in.], Wydawnictwo Krytyki Politycznej, Warszawa 2017.

Ubertowska Aleksandra, Natura u kresu (ekocyd), „Teksty Drugie” 2013, nr 1-2, s. 33-44.

White Hayden, Proza historyczna, przeł. Rafał Borysławski [i in.], Universitas, Kraków 2009.

Wyszczelski Lech, Jeńcy wojny polsko-rosyjskiej 1919-1920, Bellona, Warszawa 2014.

Tam nawet ptaki nie śpiewają. 5. Rocznica katastrofy smoleńskiej [online], http://czestochowskie24.pl/czestochowa/45350/ [dostęp: 15.03.2017]. 
Piotr Krupiński

\section{„A sky without birds": on a topos of concentration camp literature (and its margins)}

\section{(Summary)}

The main purpose of this article is to draw attention to one of the motifs which appear regularly in literature concerning the Nazi concentration camps. In many memoirs of ex-convicts the concentration camp is represented as a place ,where birds did not sing" - an area domed by an empty, silent sky, ,a sky without birds”. The author of this paper examines this phenomenon from many perspectives, drawing on various types of sources. The voices of the imprisoned are surprisingly juxtaposed with ornithological research conducted by Günther Niethammer, a scientist and, simultaneously, one of the SS guards in the Auschwitz concentration camp. This article is part of ever-growing contemporary research on the topoi of concentration camp literature and Holocaust literature. Ecocriticism and environmentalism constitute an important inspiration for his text, and a post-anthropocentric perspective allows the author to extend the scope of historicity to include the non-human beings, such as animals, plants and the landscape.

Keywords: concentration camp literature; Nazi concentration camps; topoi; birds; animal studies 